УДК 32.321.02

DOI https://doi.org/10.32782/2305-9389/2021.24.33

\title{
ПРОЦЕСИ ТРАНСФОРМАЦІЇ ГРОМАДЯНСЬКОГО СУСПІЛЬСТВА ТА ДЕЦЕНТРАЛІЗАЦІЇ ВЛАДИ: МЕХАНІЗМИ ВЗАСМОЗВ'ЯЗКІВ
}

\author{
Кравчук Ольга, \\ кандидат політичних наук, дочент, \\ доцент кафедри соціально-гуманітарних дисииплін \\ Національного університету кораблебудування імені адмірала Макарова
}

\begin{abstract}
Підтверджено, щзо місиеве самоврядування являє собою самостійну систему організації діяльності локальної спільноти (місиевих жителів) на певній території, щзо є сукупністю різноманітних органів та інститутів, котрі функиіонують як єдиний, иілісний механізм, де місиева спільнота - його провідна ланка. Така система функиіонує як сукупність організаційних форм та інститутів прямого самоврядування, через які реалізуються принциипи і функиії місиевого самоврядування.

Зроблено висновок, щуо демократичне суспільство-иесуспільство, де влада делегована елітам таздійснюється як насильство над більшістю і над меншістю. Безумовно, ие краще, ніж влада однієї людини. Але ж ми прагнемо рухатися від демократії до громадянського суспільства, де кожна людина має бути почутою.

Означено, що нині проблема співвідношення громадянського суспільства $і$ влади має виключно практичний характер, спричинений тим, щяо становлення громадянського суспільства проходить у досить напруженому протиборстві з державою, яка має надзвичайно неоднозначну $i$ внутрішньо суперечливу соціальнополітичну, ідеологічну та правову конфігурацію. У такій ситуації надії деяких дослідників на те, щуо держава піклуватиметься про розвиток громадянського суспільства, не відповідають реальному стану речей.

У статті наголошено, щзо труднощами становлення $і$ розвитку громадянського суспільства є не тільки активність держави, прагнення правлячих еліт до посилення своїх позицій у соиіумі і навіть перевищення власних повноважень. Серйозну небезпеку для формування та існування громадянського суспільства становить i діяльність різного роду корпоративно-бюрократичних структур всередині держави, незмінно принижуючи статус активності громадян.

Окреслені важливі завдання формування правової демократичної держави і громадянського суспільства в Україні: збереження громадянської злагоди й організація належного виконання та застосування законів, можливостей реалізації права, тобто виконання правом своӥх соціальних функиій повною мірою. Водночас серйозною проблемою залишається те, шзо украӥниі загалом все ще досить низько оиінюють ефективність інститутів громадянського суспільства (про шуо можна судити за рівнем довіри громадян до них та участю в їх діяльності) i недостатньо уявляють можливості їх реального застосування. Кількість тих, хто не довіряє громадським організачіям, тривалий час перевищувала кількість тих, хто їм довіряє.
\end{abstract}

Ключові слова: механізм, громадянське суспільство, держава, свідомість, нація, владна система, децентралізація, влада, трансформація.

\section{Kravchuk Olga. The processes of transformation of civil society and decentralization of power: mechanisms of interrelations}

It is confirmed that local self-government is an independent system of organizing the activities of the local community (local residents) in a certain area, which is a set of various bodies and institutions that function as a single, integrated mechanism, where the local community is its leading link. Such a system functions as a set of organizational forms and institutions of direct self-government, through which the principles and functions of local self-government are implemented.

It is concluded that a democratic society is a society where power is delegated to elites and is exercised as violence against the majority and the minority. Of course, this is better than the power of one person. But we strive to move from democracy to civil society, where everyone should be heard.

It is noted that at present the problem of the relationship between civil society and government is purely practical, caused by the fact that the formation of civil society is in a rather tense confrontation with the state, which has an extremely ambiguous and internally contradictory socio-political, ideological and legal configuration. In this situation, the hopes of some researchers that the state will take care of the development of civil society do not correspond to the real state of affairs.

It is emphasized in the article that the difficulties of formation and development of civil society are not only the activity of the state, the desire of the ruling elites to strengthen their positions in society and even exceed their own powers. A serious danger to the formation and existence of civil society is the activity of various corporate and bureaucratic structures within the state, invariably lowering the activity status of citizens.

Important tasks for the formation of a democratic state governed by the rule of law and civil society in Ukraine are the preservation of civil harmony and the organization of proper implementation and application of laws, opportunities

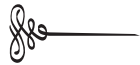


for law enforcement, in the full implementation of their social functions. At the same time, a serious problem remains that Ukrainians in general still underestimate the effectiveness of civil society institutions (which can be judged by the level of citizens' trust in them and participation in their activities) and do not sufficiently imagine the possibilities of their actual application. The number of those who do not trust public organizations has long exceeded the number of those who trust them.

Key words: mechanism, civil society, state, consciousness, nation, power system, decentralization, power, transformation.

Особливе місце в загальній структурі суб'єктів системи безпеки України посідає громадянське суспільство (політичні партії, громадські та релігійні організації, різноманітні добровольчі об'єднання, спілки та інші недержавні інституції, а також релігійні організації), відіграючи дедалі помітнішу роль у системі забезпечення національної безпеки. Як свідчать останні події в Україні, саме небайдужа патріотично спрямована громадськість здатна справити суттєвий вплив на загальний рівень національної безпеки, зокрема, через безпосередню участь у збройному захисті територіальної цілісності держави, різноманітні волонтерські організації, ЗМІ та міжнародну співпрацю.

Збалансована внутрішня система безпека держави відображає стан її політичної системи, що забезпечує стабільний розвиток суспільства, відображає інтереси всіх його соціальних груп, сприяє консолідації нації і дає змогу ефективно вирішувати завдання економічного, соціального і культурного розвитку. Внутрішня політична безпека досягається шляхом ефективної соціально спрямованої узгодженої діяльності державних органів та інститутів громадянського суспільства, що задовольняє і захищає політичні, соціальні інтереси особи та суспільних груп, сприяє досягненню стану громадської злагоди та соціального партнерства всередині держави.

Внутрішня безпека має основні складники: державно-управлінський складник, що забезпечує ефективне функціонування державної влади та системи управління органами державної влади різних рівнів; суспільно-політичний складник, у структурі якого виявляються та забезпечуються політичні інтереси окремих груп громадян та суспільства загалом, забезпечуються соціально-політичні права громадян, реалізується їх політична активність у несилових формах; суспільно-конфліктологічний складник, що забезпечує ненасильницьке розв'язання внутрішніх суспільних конфліктів; ідеологічно-інформаційний складник, що базується на ідеологічному, соціально-психологічному та інформаційному забезпеченні суспільно-політичної стабільності.

Характерною рисою сучасного політичного життя в Україні є посилення недовіри громадян до офіційних структур влади і політичних лідерів, спричинене негативними наслідками державної політики в економічній, політичній, соціальній та культурній сферах. Аналізуючи особливості української ситуації, М. Розумний зазначає надзвичайно низький рівень довіри народу до влади і переважання суспільного песимізму на тлі низької соціальної активності [4, с. 521-522].

Система забезпечення безпеки країни за своєю організаційно-функціональною та ресурсною спроможністю має, передусім, гарантувати суверенітет, територіальну цілісність, добробут та фізичну безпеку громадян. На жаль, за роки незалежності України повною мірою цього так і не вдалося досягти. Має місце розбалансування управління в системі забезпечення безпеки. Окремі політичні сили під приводом необхідності вдосконалення чинного законодавства час від часу намагалися підмінити національні інтереси приватними або корпоративними інтересами окремих фінансово-промислових чи політичних груп. Суттєву проблему становила політизація силових структур. Наслідком усього цього стали, передусім, наростання хаотичних процесів у системі забезпечення національної безпеки та перманентний відплив висококваліфікованих фахівців.

Ефективність такої співпраці держави з громадянським суспільством підтверджується досвідом США. Так, у 2007 р. в країні вперше було прийнято Національну контррозвідувальну стратегію. У 2009 р. були внесені зміни до неї, згідно з якими були поставлені нові завдання, визначена нова роль розвідувальної спільноти і контррозвідувальних органів. На ці зміни миттєво відреагували академічна й університетська спільнота. Протягом подальших півроку більше ніж у двадцяти університетах США були підготовлені проєкти відповідних програм, в яких було запропоновані конкретні шляхи вирішення поставлених завдань і підготовки необхідного для їх виконання персоналу [4].

Як показала політична історія світової демократії, активності громадських асоціацій та зростанню їх членів, перш за все, сприяють такі структурні фактори: підвищення освітнього рівня населення; розвиток суспільних комунікацій; періоди активізації політичного протесту, залучення нових рекрутів у соціальні об'єднання; реакція громадськості на знову висунуті урядові програми перетворень і т. д. Так чи інакше рівень цієї активності може починати активізувати «на місцях», тому ми говоримо про те, що децентралізація є важливою стратегічною реформою. Це не просто реформа, яка технічно змінює 
розподіл певних компетенцій чи повноважень. Можливо, це одна з реформа, яка змінить мислення та менталітет українців. Важливо, щоб громадяни самі брали на себе відповідальність, а не чекали, поки хтось згори це зробить. Цього можна навчитися як раз на місцевому рівні.

Водночас одвічними труднощами становлення і розвитку громадянського суспільства $є$ не тільки активність держави, прагнення правлячих еліт до посилення своїх позицій у соціумі і навіть перевищення власних повноважень. Серйозну небезпеку для формування та існування громадянського суспільства становить діяльність різного роду корпоративно-бюрократичних структур всередині держави, незмінно принижуючи статус активності громадян. Тому громадянське суспільство не виникає там, де люди не борються за свої права і свободи, де відсутні традиції критичного аналізу громадськістю діяльності влади i, зрештою, де політичні свободи сприймаються людьми як свавілля і відсутність відповідальності за свої вчинки.

У політичній сфері інститутами громадянського суспільства $є$ політичні партії, організації, рухи різної політичної орієнтації (праві, ліві, центристські, релігійні), що переслідують політичні цілі, беруть участь у боротьбі за державну чи муніципальну (публічну владу). Сюди ж входять молодіжні політичні організації (наприклад, комуністичні спілки молоді).

Найважливішим інститутом громадянського суспільства в політичній сфері є місцеве самоврядування, органи якого спільно з органами держави представляють систему публічної влади і $є$ сполучною ланкою між громадянським суспільством і державою. Усі вищевказані інститути спільно з державою становлять політичну систему суспільства. Своєрідністю відрізняється такий інститут громадянського суспільства, як професійні спілки (профспілки). Вони діють як у політичній, так і в економічній сфері.

Система безпеки держави досягається шляхом реалізації системи заходів, що закріплюють сталість конституційного ладу держави, дотримання демократичних процедур проведення виборів, реалізації та гарантії конституційних прав і свобод громадян, контролю діяльності органів держави громадянським суспільством. Аналіз системи індикаторів політичної безпеки в Україні свідчить про загрозливу ситуацію у політичній сфері. Зокрема, останнім часом простежуємо чітку тенденцію до порушень та обмежень прав громадян у політичній та економічній сферах, недотримання конституційних процедур під час внесення змін до Конституції України, послаблення повноважень судової гілки влади (зокрема, Верховного Суду України), утиски та репресії опозиції тощо. Важливе значення для забезпечення внутрішньої та зовнішньої політичної безпеки держави відіграють попередження та нейтралізація загроз.

Нейтралізація загроз внутрішній безпеці України можлива за умови проведення низки заходів. Це, зокрема, деполітизація та мінімізація наявних та латентних конфліктів у суспільно-політичній площині через створення спеціальної державної служби моніторингу, аналізу та прогнозування суспільних конфліктів, реалізацію та забезпечення прав і свобод національних меншин в Україні, створення та використання ефективної системи «соціального партнерства» за участі інститутів громадянського суспільства, деполітизацію та залагодження суперечок на етнічному і релігійному грунті.

Така «примітивізація» видається опосередкованим свідченням політичного нігілізму як специфічного прояву невисокої політичної культури, «помноженого» на низьку правову культуру. Нагадаємо, В. Липинський свого часу наголошував, що політична культура - це глибоке усвідомлення елітою свого не просто класового, але й національного інтересу, активна творча діяльність задля його реалізації в процесі служіння своїй державі та в здобутті політичної влади. Натомість у контексті «політики як форми самоуправління суспільства на засадах доброї волі шляхом відповідального впровадження, застосування, реформування і скасування інститутів, що імпліцитно наявна в ній», в українських реаліях спостерігається «непослідовність у дотриманні цих засад, що виявляється, насамперед, у заміні принципу права як засадничого для розуміння політики принципом інтересу». Така «підміна понять» своєю чергою «руйнує сам порядок взаємодії громадян як вільних і рівних і веде, зрештою, до тлумачення політики як підкорення одними суспільними групами інших із застосуванням страху і насильства, що, очевидно, усуває із суспільства свободу і прагнення до самоуправління, тобто перестає бути політикою» [5].

Окреме місце займає проблема незначної довіри до сектора безпеки в контексті загальної суспільної недовіри до влади (згадаймо афоризм Г. Кіссінджера про те, що «дев'яносто відсотків політики створюють погану репутацію іншим десяти відсоткам»). I ця тенденція бере початок від недовіри до управлінців місцевого рівня. Спостерігається соціально-психологічний парадокс: довіра до армії чи поліції загалом (як одного з кількох дещо абстрактних «інститутів влади») є доволі високою, і є великий острах перед «нестатутними відносинами» в армії чи «недозволеними методами ведення слідства» в поліції.

Ситуацію ускладнює також велика забюрократизованість державного апарату на всіх рівнях, 
помножена на «традиційну» корумпованість чиновництва. Боротьба з цими явищами зазвичай ведеться «від випадку до випадку» - шляхом періодичних (але разом із тим епізодичних) скорочень управлінсько-адміністративних структур та розслідування «гучних справ».

Сучасні дослідники (зокрема В. Горбулін та О. Литвиненко) вказують, що для України дуже гострою $\epsilon$ «проблема українського істеблішменту чи еліти за самоназвою» [4, с. 34]. Адже «справжня, будемо називати iï національна, еліта в Україні лише формується» [1]. Ключовий «підтекст» цієї проблеми полягає в тому, що нинішній «владний істеблішмент» (тобто поточні «носії державної влади») хоче остаточно ототожнити себе 3 «державною елітою» (як перманентними виразниками «волі народу» і носіями «високої культури», захисниками «національних інтересів» та «національних цінностей»): «Те, що український істеблішмент нині неспроможний якісно реалізовувати загальносуспільні функції, давно вже стало загальним місцем громадської дискусії. При цьому претензії сягають неба - аж до проголошення себе новітньою українською аристократією» [4, с. 34]. За свідченням академіка В. Литвина, проблеми державного будівництва випливають із того, що «в нас немає політичної еліти, в нас є правлячий політичний клас» [5, с. 4].

Тому крізь призму централізації влади похідна проблема полягає не тільки в ідентифікаційній «підміні понять» («владний істеблішмент» та «державна еліта») - вона сягає глибшої «підміни інтересів», коли інтереси певної групи людей (прошарку еліти або навіть псевдоеліти) видаються за цілісні «національні інтереси», нав’язуються і закріплюються політико-правовими («недоторканість» тощо), політико-економічними (пільги тощо) і т.п. механізмами.

Породжуване такими процесами розшарування суспільства є викликом національній безпеці, породжуючи не тільки «політичну корупцію», але й протестні настрої (соціальну напругу) та соціальнополітичний нігілізм (що підриває розвиток політичної культури).

Таким чином, однією 3 головних умов протидії політико-правовим деструкціям влади є належний розвиток громадянського суспільства. Життєздатне громадянське суспільство може протистояти застою i $€$ антиподом тоталітарному режиму. Чим більш розвиненим $є$ громадянське суспільство, 3 міцною економікою, постійним зростанням добробуту населення, цілісною національною системою освіти, культури, науки, охорони здоров'я, незалежними, технологічно забезпеченими ЗМІ, досконалою сферою судового захисту прав і свобод людини, тим легше громадянам захищати свої інтереси, тим ширшими $\epsilon$ їхні можливості щодо самореалізації в різних сферах суспільного життя і тим меншою є небезпечність узурпації політичної влади тими чи іншими її органами або окремими особами.

Відстоюючи матеріальну і духовну незалежність людини від держави, домагаючись правової гарантії такої незалежності, захисту приватних і суспільних інтересів людей, громадянське суспільство активно сприяє процесам політичної демократизації, набуттю державою ознак держави правової [5, с. 394].

Нові дослідження показують, що сутність і природа місцевого самоврядування полягають у розумінні його ролі як основоположного інституту громадянського суспільства, як самостійної форми здійснення народом публічної влади. Ця концептуальна позиція доповнюється певними рисами місцевого самоврядування: населення локальної спільноти виступає специфічним суб'єктом місцевого рівня влади; питання місцевого значення стають особливим об'єктом керування у відносинах місцевого самоврядування; самостійність місцевої влади, ï порівняна автономність, незалежність від державної влади; власна відповідальність муніципальних громад за діяльність у середовищі місцевого самоврядування [1, с. 94].

3 метою запобігання деструктивних дій та рішень влада має вдосконалювати механізм виконання своїх функцій та створення впливових засобів забезпечення власної діяльності, оптимізувати структури управління, розумно розмежувати повноваження, права і відповідальність у всій владній вертикалі, скоротити нераціональні витрати, пов'язані з функціонуванням органів влади та органів, що забезпечують їхню діяльність, сприяти налагодженню механізму контролю за діями влади з боку суспільства.

На жаль, специфіка функціонування влади в сучасній політичній ситуації в Україні полягає в тому, що тут має місце напластування різновекторних і різномасштабних чинників, які гальмують процес консолідації суспільства і його політичної та бізнесової еліти. В Україні діє низка рівносильних політико-економічних груп, кожна з яких намагається змінити ситуацію на свою користь. Якщо в демократичних державах світу з розвиненою партійною системою політична ініціатива народжується знизу і спрямовується вгору, тобто від громадянина до інституції, а політичні партії природно випливають із громадських організацій і є організованою громадською думкою, котра об'єктивно відображає суспільні потреби та інтереси, на основі яких і формуються передвиборні програми, то в сучасній українській політичній практиці, яка є продуктом олігархічної партійної системи, все відбувається навпаки: за великі мафіозні гроші рекрутуються політичні солдати, готові виконувати будь-яку роботу, починаючи 
3 політичного вбивства і завершуючи відвертою антидержавною діяльністю. За цих умов влада не гребує популістськими рішеннями, наслідки реалізації яких призводять до системної деструкції як самої влади, так і суспільства [4, с. 457].

Щоб подолати деструктивний вплив на розвиток громадянського суспільства, потрібні злагоджені і ефективні дії влади, політикуму, бізнесу та громадськості, дії, що грунтуються на визначених і узгоджених суспільних пріоритетах та усвідомленні місця та ролі України у світі.

Конструктивна взаємодія громадянського суспільства 3 державою передбачає: ініціювання ухвалення політичних рішень органами влади, що тим самим спонукає до активності саму державу; зміцнення приватної ініціативи, що дає змогу розв'язати низку економічних і соціальних проблем без втручання держави (організація громадсько-корисних видів діяльності, благодійних фондів, недержавних навчальних закладів і т. д.); формування політичної культури громадян, у тому числі громадянських форм поведінки.

Громадянське суспільство повинно мати право контролю за діяльністю державних службовців. Жодна форма громадянського управління не буде корисною й ефективною, якщо громадяни не володіють і не користуються мудрими методами для керівництва та контролю діяльності посадових осіб і державних службовців. Нині форми такого контролю відсутні. Це означає фантастичне зростання закритості влади щодо суспільства, що є причиною зловживань і злочинів у сфері управління. Дуже важливою $є$ наявність у суспільстві розумних та підготовлених представників. Існування демократії залежить від успіху представницького управління, що спричинено практикою обрання на державні посади тільки професійно підготовлених, інтелектуально компетентних, соціально лояльних і морально гідних громадян. Лише за таких умов може зберегтися уряд, що обраний народом, існує за допомогою народу і діє на благо народу [3, с. 369].

Подальше становлення в Україні демократичної, правової держави із соціально орієнтованою економікою вимагає гармонізації відносин між державою і населенням, усіма інститутами громадянського суспільства, відновлення престижу органів, які здійснюють державне управління. Нагальним $\epsilon$ проведення реформування регіонального рівня. Але цьому на заваді стають ментальність радянських часів, небажання, а іноді і побоювання запровадити механізми делегування функцій і повноважень на нижчі рівні державної влади. Забезпечення прозорості в підготовці і прийнятті державних рішень можливе лише за умов формування повноцінних інститутів громадянського суспільства, зокрема: незалежних засобів масової інформації, мережі неурядових аналітичних центрів, впливових політичних партій, які беруть участь у формуванні органів влади і несуть публічну відповідальність за їхню діяльність [1, с. 36].

\section{Література:}

1. Горбулін В.П., Литвиненко О.В. Національна безпека: український вимір. Київ : ПП «Інтертехнологія», 2008. 234 с.

2. Громадянське суспільство: політичні та соціально-правові проблеми розвитку : монографія / за ред. ред. М.П. Требіна. Харків : Право, 2013. 536 с.

3. Національна безпека України в етноментальному та міжнародному вимірах / Данильян О.Г., Дзьобань О.П., Калиновський Ю.Ю., Моісеєва Н.І. Харків, 2004. 205 с.

4. Розумний М.М. Екстремізм і радикалізм у смисловому полі української політики : Українська політична нація: генеза, стан, перспективи : монографія / за ред. В.С. Крисаченка. Київ : НІСД, 2003. 560 с.

5. Щедрова Г. Громадянське суспільство: прагнення та реалії. Наук. зап. Ін-ту політ. і етнонаи. дослід. НАН Украӥни. Сер.: Політологія і етнологія. 2004. Вип. 25. С. 234-246. 